\title{
Multifaceted Linguistic Pragmatics of Justification (Ukrainian Speech-Based Study)
}

\author{
Natalya Kravchenko ${ }^{*}$, Viktoriia Blidchenko-Naiko² \\ ${ }^{1}$ Translation Department, National University of Life and Environmental Sciences of Ukraine, Kiev, Ukraine \\ ${ }^{2}$ Department of Ukrainian Studies, Bogomolets National Medical University, Kiev, Ukraine \\ Email: ${ }^{*}$ kravchenko@outlook.com
}

How to cite this paper: Kravchenko, N., \& Blidchenko-Naiko, V. (2020). Multifaceted Linguistic Pragmatics of Justification (Ukrainian Speech-Based Study). Open Journal of Modern Linguistics, 10, 11-22. https://doi.org/10.4236/ojml.2020.101002

Received: December 23, 2019

Accepted: January 17, 2020

Published: January 20, 2020

Copyright (c) 2020 by author(s) and Scientific Research Publishing Inc. This work is licensed under the Creative Commons Attribution International License (CC BY 4.0).

http://creativecommons.org/licenses/by/4.0/

(c) (i) Open Access

\begin{abstract}
This paper investigates the communicative act of justification as a multifaceted pragmatic and structural phenomenon. We argue that the properties of justification rely on the amount of face threat to be compensated by such an act, on the number of face-threatened communicators and the function of justification as a face threat-preventive or face threat-restoring device. Based on such criteria, the article identifies: 1) justification-prevention of the other's face-threatening act and 2) justification-explanation/repair of the own facethreatening act. Such acts have the same illocutionary point but differ in degree of their strength, determining their different structural and pragmatic features. Justification-repair iconically reproduces the awkwardness of the denoted situations and correlates with the conversational-analytical notion of dispreference. It involves complication in verbal arrangement and interplay of multifacet pragmatics: indirect speech acts, which affect a refusal strategy of justification, correlate with the strategies of negative politeness and their corresponding maxims, which, in their turn, involve the cooperative maxims' violation triggering the conversational implicature to communicate face-threats in an implicit way. Justification-prevention is subdivided into prepositional and postpositional types in regards to their auxiliary position in complex speech acts. They differ structurally and pragmatically, depending on the number of face-threatened participants. Prepositional justification is intended to compensate face-threats both to the interlocutor who may be imposed by the speaker's act and to the speaker, who takes risk to be faced with refusal or rejection. It is less distinct and more structurally and pragmatically complex as compared to the postpositional justification that prevents the damage only to the speaker's face.
\end{abstract}

\section{Keywords}

Justification-Prevention, Justification-Repair, Indirect Speech Acts, Negative 
Politeness, Maxims of Politeness, Cooperative Maxims, Conversational Implicatures

\section{Introduction}

The paper addresses one of the key problems in the field of modern pragmatics-the issue of interplay of different pragmatic phenomena (Ariel, 2012; Hassoon \& Saffah, 2017; Kravchenko \& Pasternak, 2018; Kravchenko, 2017a, 2017b) with focus on actions that promote face-preservation by means of communicative acts of justification. The choice of the research topic is due to insufficient study of the act of justification-especially in terms of its taxonomic, structural-semantic and illocutionary properties within the framework of the act's faceredressive functions and its interplay with other pragmatic phenomena. Designated focuses determine the significance of the paper for in-depth investigation of the pragmatic concepts of face, face-related politeness and cooperation and illocutionary meaning.

Presuming some isomorphism between structural arrangement of this act, its illocutionary properties and specifics of embarrassing situations, involving justification as a face-redressing action, the paper attempts to explore the phenomenon under discussion within integrative framework of conversational analysis (Nishizaka \& Hayano, 2015; Levinson, 2006; Pillet-Shore, 2017; Robinson \& Bolden, 2010; Sidnell, 2010), concepts of face, face-work and politeness (Brown \& Levinson, 2011; Brown, 2017; Leech, 2014, 2016; Ogiermann, 2009) as well as the illocutionary force theory (Asher \& Lascarides, 2001; Levinson, 2017; Searle \& Vanderveken, 1985) and some findings of the Grice's and neo-Gricean inferential pragmatics (Grice, 1975; Bach, 2012). Such integrative framework determines the topicality of the research.

In the methodological framework of the speech acts' theory the idea about justification as an auxiliary speech act, was first coined by Van Dijk (1977: p. 202) who considered this act as a sufficient condition for the successfulness of a main act. However, this idea was not developed in further pragmatic studies either in terms of identifying the structural types of such an auxiliary act, or their different face-redressive functions.

Goetz (2010: p. 403) states that justification is the way to negotiating the social world, when people justify for their actions or thoughts based on inferences about the feelings and beliefs of others. According to Hornby (2010: p. 843), justification means the giving of an explanation or excuse for something or for doing something. However, in some works the act of justification is explored with enhancing its difference from explanation or excuse (Hassoon \& Saffah, 2017).

Though certain amount of research has explored the act of justification from different perspectives (Benoit, 1995; Goetz, 2010; Hassoon \& Saffah, 2017; Kir- 
chhoff et al., 2012; Robinson, 2016), the set of problems to specify this pragmatic phenomenon remained unsolved. They might be explicated by the set of the following questions: Are there any differences between justification performed to avoid somebody's face-threatening acts and justification aimed to justify the own dispreferred actions? Does the illocutionary force of justification and its structural arrangement depend on its preposition or postposition in regards to information to be justified? How do design features of justification either as an auxiliary part of the complex speech act or an independent speech move impact its illocutionary and face-redressive properties?

The answers to these questions determine the algorithm of the analysis undertaken in the paper and explain the primary aim of the article: to categorize the acts of justification as a multifacet pragmatic phenomenon, whose pragmatic and structural complexity are iconically triggered by the degree of "delicacy" of situation it refers to.

\section{Research Methods and Data}

The material of the study consists of the episodes of naturally occurred dialogues of Ukrainians to elucidate how participants design their justifications to avoid/to compensate for dispreferred speech moves in embarrassing situations. The corpus of dialogues has been recorded in different communicative situations with participants of different ages, social statuses and professions in order to identify and synthesize findings about the most systematic and invariant pragmatic features of justification irrespective of sociolinguistic variables.

To identify appropriate participants, we have based on the phenomenon being investigated, and evidence informing the study. A focus group of 50 persons has been considered primarily on the basis of the criterion of Ukrainian ethnicity. When selecting participants, criteria such as gender, occupation, social status, were deliberately not taken into account. Participants were offered to discuss one of the "sensitive" topics, involving the use of an act of justification. Nevertheless, at least a third of the research material has involved spontaneous dialogs, recorded with the permission of the participants. This allowed us to identify new "delicate" situations requiring justification that could otherwise be overlooked.

With the view of comprehensive study, the corpus of material has been divided into groups based on criteria that presumably effect illocutionary potential and face threat compensative properties of justification. The two main groups involve the acts of justification aimed at 1) prevention the other's face-threatening act or 2) explaining the own face-threatening act.

The research methodology is based on the following research methods: form/ function pragmatics in exploring pragmatic meanings, conventionally associated with specific linguistic expressions (Ariel, 2012: p. 30) Literal Force Hypothesis (Levinson, 2006, 2017; cited in Kravchenko, 2017a), suggesting that the indexes of illocutionary force are built into the utterance surface form (to determine the structural markers, which contribute to reinforcement or decreasing of justifica- 
tion illocution); the Grice's and neo-Gricean inferential pragmatics (to inference conversational implicatures aimed at communicating face-threatening meaning in an implicit way); explanatory tools provided by speech acts theory (to identify indirect speech acts with directive illocution to effect a refusal strategy of justification as well as to specify felicity conditions that are constitutive of a particular kind of act); Brown and Levinson's politeness theory and the Politeness Principle theory to clarify the strategies and maxims of politeness involved by different types of justification; conversational-analysis (to examine the ways in which justification accomplishes particular social actions and reproduces the specifics of the situation it refers to; to identify the markers of dispreferred speech moves in their correlation with the face demands).

\section{Results and Discussions}

\subsection{Justification-Prevention: Prepositional and Postpositional Types}

The analysis of the data has shown that justification-prevention the other's face-threatening act might be either in preposition or postposition in regards to the main information to be justified. Examples (1a)-(1e) show that preposition type of justifications are less distinct, unambiguous and structurally simpler than a postposition one as in (2a)-(2c).

(1a) Кажуть, конференція буде цікавою. Ти будеш брати участь?

(The conference is said to be interesting. Will you participate?).

(1b) Вчора я купила чудову сукню. Але, на жаль, вона мені замала. Ти не хочеш ї̈ помріяти?

(Yesterday I bought a nice dress. But, unfortunately, it is skimpy for me. Don't you want to try it on?).

(1c) Уявляєш, я знов забула свій телефон. Чи можу я скористатися твоїм?

(Only think! I have forgotten my phone again. Can I use yours?).

(1d) Чесно кажучи, я не фахівець у вашій сфері і моє запитання може здатися дещо дилетантським, але мені все ж таки хотілося 6 почути на нього відповідь

(Honestly, I'm not familiar with your field. And my question may seem you a pretty tenuous but I still would love to hear the answer to it).

(1e) Сьогодні така чудова погода! Як ти щодо того, щоб піти погуляти?

(Today is such a wonderful weather! What about a short walk?)

All above examples represent the complex speech acts with justification as an auxiliary information to mitigate a subsequent implicit imposing (face-threatening act).

Taking into account the claimed multifaceted angle of our study, let us dwell on the above examples in the framework of face and politeness strategies as well as conversation analytic findings about preference organization and dispreferred 
speech moves.

In (1a)-(1e) prepositioned justification specifies particular reasons to justify the speaker's subsequent request, invitation, advice or offer. Therefore, this auxiliary part solves several tactical tasks:

1) it makes the actions expected by the speaker from the addressee more acceptable;

2) it has some implications for satisfying the addressee's negative face by mitigating the face threatening act of imposition and thus realizing the maxim of tact;

3) it provides as much information as it is required to specify the conditions for a subsequent "embarrassing" act as one that somehow meets the hearer's interests. In this way the speaker a) satisfies a benefit felicity condition particularly important for directives and b) adheres to maxims of quantity, manner and relevance of information.

In terms of conversational analysis (Robinson, 2016; Robinson \& Bolden, 2010) prepositioned justification may be considered as a kind of sequence-initiating or presequential move aimed to save the face of both participants by preventing or minimizing the danger of the addressee's "dispreferred" act. Based on the illocutionary properties of the subsequent act, justification may accomplish the functions of prerequest as in (1c), including prerequest for information as in (1d), preinvitation as in (1e), preoffer as in (1b) and preadvice as in (1a).

A complex speech act, which incorporates the act of prepositional justification, can be schematically represented as follows:

Prepositional justification (auxiliary act) + Indirect directive (main act). I

In this regard, pragmatics of the main act that implements directive illocution deserves special attention. In addition to its pre-sequential function aimed at minimizing the danger of the addressee's possible "dispreferred" act of refusal, prepositional justification also serves as a mitigation of the subsequent main part, which primarily conveys the directive illocution (go for a walk with me; take part in a conference; buy dress from me; answer my question; give me your phone) though not expressed explicitly. In addition, the main act of implicit directive is marked by various hedges and mitigation devices.

Thus, in (1b) the mitigation means are exemplified by pragmatic assessment marker “на жаль” (unfortunately) and discourse marker “але” (but).

In (1a) a parenthetic hedge "кажуть" (is said) partially impersonalizes the speaker, and thus scales down the responsibility for his/her words: the speaker will not be held responsible for the fact that the conference is not interesting since "is said" does not satisfy the essential felicity condition for assertive “конференція буде цікавою" (The conference will be interesting) decreasing its illocutionary force (in contrast to the factitive verbs "know", "be aware", etc., implying the factitive presuppositions that their object/complement is true (see Kravchenko, 2017a: p. 152).

In (1d) there is an accumulation of face-preservation devices, including 1) mitigation by means of modals in "може здатися"/ may seem ("may" as a modal 
verb of probability occurs in combination with an impression verb "seem") and “хотілося 6 почути" (would love to hear), as well as an adverbial modifier “дещо" (pretty), 2) hedging by means of parenthesis “чесно кажучи" (honestly), discourse marker "але" (but), and additive particle “все ж таки" (still).

Such structural markers correlate with the degree of face threat, contained in the main speech move of the speaker, whose request for information might be (with certain probability) damaging for the addressee's face. At the pragmatic level structural complication in (1d) corresponds to the politeness maxims of 1) modesty (admitting the lack of his professionalism the speaker minimizes any possible praise for a smart question), 2) generosity (diminishing his value as a specialist, the speaker helps to confirm the other person's importance), 3) tact (related to increased politeness: hedges and mitigation in justification significantly decrease the degree of the imposition and, vice versa, confirm the addressee's right to own opinion) and 4) agreement (admitting the lack of his professionalism, the speaker deprives himself of possibility to disagree with the addressee's "more professional" response).

In its turn, the maxim of tact (increased politeness) correlates with flouting of the cooperative maxim of quantity of information since in his/her effort to minimize the face threat the speaker is too verbose. The maxim violation triggers the implicature, which is a face-protective for the addressee: "an incorrect answer can be explained by an incorrect (unprofessional) question formulation".

As shown by the above analysis, prepositioned justifications differ in their structural arrangement. Most probably, there is a strict dependence between the structural complexity of justifications and the degree of dispreference of information, provided by the main part of the speaker's complex act, since both of these features relate to the scale of the face threat to the partner's face.

Our observations are in line with the latest findings of conversational analysts about preferred and dispreferred speech moves and their different implications for "face". According to Pillet-Shore (2017: p. 2), participants display their orientation to actions as "preferred" by producing them straightforwardly-without delay, qualification, or account. Correlatively, participants treat actions as "dispreferred" by withholding, delaying, qualifying, and/or accounting for them. "Dispreferred" moves are "marked with hesitations and particles" (Levinson, 2006: p. 48 ) as well as other markers of structural complexity.

If we reconsider (1d), we can see that the structural complexity of justification here iconically reproduces the confused situation of asking the person in the presence of other people, who, moreover, are interested in his/her answer and are capable to assess it from professional viewpoint.

For the same reason, the main part of a complex act with prepositioned justification (that is, the actual request, invitation, advice or offer) often conveys the deliberate indirectness associated with implicated directive illocution: " $Т и$ будеш брати участь?"(Will you participate?) in (1a) actually means "take part!";

“Чи можу я скористатися твоїм?" (Can I use yours?) in (1c) means "give me 
your phone”; “мені все ж таки хотілося 6 почути на нього відповідь» (but I still would love to hear the answer to it) in (1d) means "answer my question!".

Question arrangement of the directives reduces distinctness of the statements thus giving the addresser the possibility to treat directive illocution as an alternative, rather than an obligation. Due to scaling down an imposition, the "call to action" may result in optional perlocutionary reaction (for example, "No, I don't") in response to indirect offer "Ти не хочеш їі помріяти?" (Don't you want to try it on?) in (1b). Moreover, in the same (1b) we can observe the flouting of the maxims of quality and relevance of information, since the speaker has not disclosed an essential part of information (why exactly the addressee should try the dress on) and expresses it in an ambiguous way. As a result, the maxims' flouting triggers the conversational implicature, which matches here the directive illocutionary force and restores completeness and unambiguity of information (a fully informative statement would sound like "I want you to buy this dress").

As stated before, justification might be either the prepositional as in (1a)-(1e) or postpositional, when the speaker first produces the main speech act and then justifies what has been said before as in (2a)-(2c).

A complex speech act, which incorporates the act of postpositional justification, can be schematically represented as follows:

The act of recognition of own failure, incompetence, weakness (main act) + Postpositional justification (auxiliary act).

If to compare the prepositional and postpositional justifications, we can conclude that the latter are more distinct, unambiguous and structurally simpler, distinguished by the lack of hedges, mitigation, modals, complex sentences, parenthetical words, etc., as shown by the following examples.

(2а) Я ще не звітував з наукової роботи. Ще не знаю, коли остання моя стаття буде надрукована

(I have not yet reported on scientific work. I do not know yet when my last article will be printed).

(2b) Я не встигла приготувати вечерю, оскільки щойно повернулася 3 роботи.

(I did not have time to cook dinner because I just got back from work).

(2c) $Я$ не розуміюся на концептуальному мистецтві. Гадаю, на ньому взагалі мало хто розуміється.

(I do not understand conceptual art. I think there are few who understand it at all).

In our opinion, such differences can be explained by the amount of face threat. It is quite obvious, that a single and a double threat are not treated by the speaker as equally valued. Prepositional justification is intended to compensate two directional face-threats: to the interlocutor who is at risk of being imposed by illocutionary threatening act of the speaker and to the speaker's face (if he fails in his efforts to "prepare the ground" and is faced with refusal or rejection). Therefore, this type of justification interplay with negative and positive faces' de- 
mands, satisfying the hearer's negative face while preventing a threat to the speaker's positive face, who may be denied a request or proposal.

Meanwhile, in postpositional justification the speaker should cope only with repairing (or preventing) the damage to his/her positive face as it is displayed in (2a)-(2c), when he himself feels awkward for something (his lack of competence in something, unfinished business, etc.), that is, he puts himself in an awkward situation and applies the act of justification to make up for it.

\subsection{Justification-Repair}

However, the degree of structural complexity significantly increases when justification is no longer used as an act that introduces a delicate situation, aimed to prevent the other's dispreferred move, but associates with the necessity to justify the own dispreferred move of disagreement, rejection or other face damaging act. The need of the speaker to avoid by justification-prevention the addresser's dispreferred act is distinctly different from the need to justify own dispreferred speech move by means of justification-repair as it is displayed in (3a)-(3c).

(3а) Мені прикро про це казати, але, боюсь, я не зможу прийняти вашу пропозицію. Річ у тому, що мене вже запросили у іншу агенцію і мені не зовсім зручно їм відмовити

(I'm sorry to say this, but I'm afraid I will not be able to accept your offer. The fact is that I have already been invited to another agency and I'm not quite comfortable to refuse them).

(3b) На жаль, я не можу вас сьогодні відвідати. Мені нездужається

(Unfortunately, I can not visit you today. I'm sick).

(3c) Я чудово вас розумію. Нас також колись заливали. Але і ви нас зрозумійте-нас тоді не було вдома. До того ж, ніхто не знав, коли включать воду. Може, можна якось це владнати?

(I understand you very well. We also were once doused. But you also understand that we were not home at the time. In addition, nobody knew when they would turn on the water. Maybe we can somehow manage it?).

A complex speech act, which incorporates the act of justification-repair, can be schematically represented as follows:

The act of mitigated refusal/rejection/disagreement (main act) + Justification-repair (auxiliary act).

Above justifications incorporate a lot of markers of structural complexity iconically reproducing the delicacy or awkwardness of the denoted situations resulted from rejection of the interlocutor's proposition as in (3a), request as in (3b) and suggestion as in (3c). Therefore, a threat to hearer's self-image associated with his/her positive, requires particular face-redressive means.

Such markers include the means of impersonalization primarily manifested by: impersonal sentences: “Мені прикро" (I'm sorry to say this), мені не зовсім зручно" (I'm not quite comfortable) in (3a) and "Мені нездужається" (I'm 
sick) in (3b); indefinite-impersonal sentences "Нас тоді не було вдома" (we were not home at the time) in (3c); indefinite-personal sentences "мене вже запросили" (I have already been invited) as in (3a), "Нас також колись заливали" (We also were once doused) and "ніхто не знав, коли включать воду" (nobody knew when they would turn on the water) in (3c). Due to these means the actions occur as though independently of the subject of a speech scaling down his/her responsibility.

It is important to emphasize that Ukrainian impersonal, indefinite-personal and indefinite-impersonal sentences often "lose" their impersonal connotations when translating then into English. Such observation requires further research of the communicative act of justification in an aspect of contrastive studies of grammatical means from the standpoint of axiological and cultural dominants of particular ethnos.

Other markers of justification as the dispreferred speech move include hedging by means of parenthesis "боюсь" (I'm afraid) and "річ у тому" (The fact is) in (3a), “на жаль" (unfortunately) in (3b), “до того ж” (in addition), and "може" (maybe) in (3c); mitigation by the modal in combination with the degree adverb (“можна якось це владнати?”/Maybe we can somehow manage it?), adverbial modifier “не зовсім зручно” (not quite comfortable) in (3a), means of generalization: “ніхто не знав" (nobody knew) and “це владнати" (manage it?). Since all these markers distance the speaker from his/her own face threatening acts, they may be considered the negative politeness means from viewpoint of politeness. However, in (3c) the speaker also employs the positive politeness strategy of attending to the hearer's needs as well as the politeness maxim of agreement seeking out some "common interests" and the referring to it: “Я чудово вас розумію. Нас також колись заливали” (I understand you very well. We also were once doused). In addition, structural complexity of (3c) indicates the flouting of the maxim of quality of information resulted in the conversational implicature: We do not feel responsible for what happened to you and we are not going to compensate you for the damage.

The identified types of justification in the naturally occurred speech of Ukrainians have been summarized in Table 1.

Table 1. Types of justification as the face-redressive device.

\begin{tabular}{|c|c|c|}
\hline \multicolumn{2}{|c|}{ Justification-prevention of the other's face-threatening act } & \multirow{2}{*}{$\begin{array}{l}\text { justification-repair of the own face-threatening act } \\
\text { Independent act, Response to face threatening act with } \\
\text { directive allocution, }\end{array}$} \\
\hline Prepositional Justification/auxiliary act & $\begin{array}{l}\text { Postpositional } \\
\text { Justification/auxiliary act }\end{array}$ & \\
\hline $\begin{array}{l}\text { 1. Mitigate the addresser's face-threatening act of } \\
\text { imposition; } \\
\text { 2. Minimize the danger of the addressee's } \\
\text { dispreferred act. }\end{array}$ & $\begin{array}{l}\text { Repair/prevent the damage to the } \\
\text { addresser's face }\end{array}$ & $\begin{array}{l}\text { 1. Justify and mitigate the own dispreferred act of } \\
\text { refusal/rejection. } \\
\text { 2. Save the other's and the own faces. }\end{array}$ \\
\hline $\begin{array}{l}\text { Redress double two-directional face threat with } \\
\text { middle strength of justification illocutionary point }\end{array}$ & $\begin{array}{l}\text { Redress one-directional face-threat } \\
\text { with minimal strength of } \\
\text { justification illocutionary point }\end{array}$ & $\begin{array}{l}\text { Redress double two-directional face-threat with } \\
\text { maximum strength of justification illocutionary point }\end{array}$ \\
\hline
\end{tabular}


In the framework of multifaceted pragmatics, justification as the dispreferred speech move involves the interplay of different pragmatic phenomena: indirect speech acts, which realize a refusal strategy of justification and correlate with strategies of negative politeness and their corresponding maxims, which, in their turn, involve the cooperative maxims' violation triggering the conversational implicature to communicate face-threats in an implicit way.

\section{Conclusion}

The paper identifies the pragmatic and structural properties of justification as a face-redressing act isomorphic to the specifics of embarrassing situations it refers to.

We introduced the new notions of the justification-repair aimed at the face restoring and justification-prevention intended to prevent face threat. The latter may be manifested by prepositional and postpositional justifications in regards to their auxiliary position and illocutionary functions in complex speech acts. Prepositional and postpositional justifications differ in structural and pragmatic markers, depending on the number of face-threatened people and corresponding amount of face threat to be prevented.

Prepositional justification is intended to compensate two directional facethreats: to the interlocutor who is at risk of being imposed by illocutionary threatening act of the speaker, and to the speaker, who may be faced with refusal or rejection. Thus, it simultaneously correlates with two face wishes and two types of politeness strategies: by mitigating a subsequent imposition implicated by requests, suggestions or advice, the speaker satisfies the addressee's negative face. At the same time, by mitigating a threat to his/her own face, the speaker in a case of refusal, satisfies his/her own positive face.

In postpositional justification the speaker should cope only with redressing or preventing the damage to his/her positive face.

Such types of threats are not treated by the speaker as equally valued, which entails less distinct, more ambiguous and structurally complex prepositional justifications as compared to the postpositional ones.

Justification-explanation (repair) of the own face-threatening act aimed at restoring the interlocutor's face is more structurally and pragmatically complex in comparison to justification-prevention of the face threat since the former iconically reproduces awkwardness of the situations of refusal, disagreement, disapproval and rejection it must explain. Justification-repair is associated with the redressing of the hearer's positive face by minimizing a threat to his/her selfimage, resulted from rejection of the other person's requests, suggestions and advices.

Structural complication of justification-repair involves impersonalization manifested by impersonal sentences, passive voice, means of generalization, as well as parenthetic markers of hedging, mitigation devices, i.e. adverbial modifiers, modals and other markers of dispreferred speech move requiring face-compensative 
actions. Such markers distance the speaker from his/her own face threatening acts scaling down his/her responsibility for the embarrassing situation.

The pragmatic facet of dispreference implies the interplay between the indirect speech acts with directive illocution to affect a refusal strategy of justification, strategies of negative politeness and their corresponding maxims, which, in their turn, involve the cooperative maxims' flouting with triggering the conversational implicature to communicate face-threatening meaning in an implicit way.

The research provides an appropriate theoretical framework for some practical implications for how to deliver and apply the different types of justification as a part of a face threat-preventive or face threat-restoring strategies depending on the type of face-threats. However, specific practical recommendations on the application of such strategies are one of the prospects for future research.

\section{Conflicts of Interest}

The authors declare no conflicts of interest regarding the publication of this paper.

\section{References}

Ariel, M. (2012). Research Paradigms in Pragmatics. In K. Allan, \& K. M. Jaszczolt (Eds.), The Cambridge Handbook of Pragmatics (pp. 23-45). New York: Cambridge University Press. https://doi.org/10.1017/CBO9781139022453.003

Asher, N., \& Lascarides, A. (2001). Indirect Speech Acts. Synthese, 128, 183-228. https://doi.org/10.1023/A:1010340508140

Bach, K. (2012). Saying, Meaning, and Implicating. In K. Allan, \& K. M. Jaszczolt (Eds.), The Cambridge Handbook of Pragmatics (pp. 47-68). New York: Cambridge University Press. https://doi.org/10.1017/CBO9781139022453.004

Benoit, W. L. (1995). Accounts, Excuses, and Apologies: A Theory of Image Restoration Strategies. Albany, NY: State University of New York Press.

Brown, P. (2017). Politeness and Impoliteness. In Y. Huang (Ed.), Oxford Handbook of Pragmatics (pp. 383-399). Oxford: Oxford University Press.

Brown, P., \& Levinson, S. C. (2011). Politeness: Some Universals in Language Use. In D. Archer, \& P. Grundy (Eds.), The Pragmatics Reader (pp. 283-304). London: Routledge.

Goetz, P. J. (2010). The Development of Verbal Justifications in the Conversations of Preschool Children and Adults. First Language, 30, 403-420. https://doi.org/10.1177/0142723710370522

Grice, H. P. (1975). Logic and Conversation. In P. Cole, \& J. L. Morgan (Eds.), Syntax and Semantics (Vol. 3, pp. 41-58). New York: Academic Press. https://doi.org/10.1163/9789004368811_003

Hassoon, H., \& Saffah, M. D. (2017). Justification, Excuse and Explanation. International Journal of Advanced Research, 5, 1426-1433. https://doi.org/10.21474/IJAR01/5662

Hornby, A. S. (2010). Oxford Advanced Learner's Dictionary. Oxford: Oxford University Press.

Kirchhoff, J., Wagner, U., \& Strack, M. (2012). Apologies: Words of Magic? The Role of Verbal Components, Anger Reduction, and Offence Severity. Peace and Conflict: Journal of Peace Psychology, 18, 109-130. https://doi.org/10.1037/a0028092 
Kravchenko, N. (2017a). Illocution of Direct Speech Acts via Conventional Implicature and Semantic Presupposition. Lege Artis. Language Yesterday, Today, Tomorrow. The Journal of University of SS Cyril and Methodius in Trnava, 2, 128-168. https://doi.org/10.1515/lart-2017-0004

Kravchenko, N. K. (2017b). Indirect Speech acts via Conversational Implicatures and Pragmatic Presuppositions. Cognition, Communication, Discourse, 14, 54-66.

Kravchenko, N., \& Pasternak, T. (2018). Multifacet Pragmatics of Russian Post-soviet Jokes. In A. Sover (Ed.), The Languages of Humor: Verbal, Visual, and Physical Humor (pp. 120-136). London: Bloomsbury Publishing.

Leech, G. (2014). The Pragmatics of Politeness. Jericho: Oxford University Press,

Leech, G. (2016). Principles of Pragmatics. London \& New York: Longman. https://doi.org/10.4324/9781315835976

Levinson, S. C. (2006). On the Human "Interaction Engine”. In N. J. Enfield, \& S. C. Levinson (Eds.), Roots of Human Sociality: Culture, Cognition and Interaction (pp. 39-69). Oxford: Berg.

Levinson, S. C. (2017). Speech Acts. In: Y. Huang (Ed.), Oxford Handbook of Pragmatics (pp. 199-216). Oxford: Oxford University Press. https://doi.org/10.1093/oxfordhb/9780199697960.013.22

Nishizaka, A., \& Hayano, K. (2015). Conversational Preference. In K. Tracy, C. Ilie, \& T. Sandel (Eds.), The International Encyclopedia of Language and Social Interaction (pp. 229-236). Boston, MA: John Wiley \& Sons. https://doi.org/10.1002/9781118611463.wbielsi071

Ogiermann, E. (2009). On Apologizing in Negative and Positive Politeness Cultures. Amsterdam: John Benjamins Publishing Company. https://doi.org/10.1075/pbns.191

Pillet-Shore, D. (2017). Preference Organization. Oxford Research Encyclopedia of Communication. Oxford: Oxford University Press. https://scholars.unh.edu/comm_facpub https://doi.org/10.1093/acrefore/9780190228613.013.132

Robinson J. D., \& Bolden, G. B. (2010). Preference Organization of Sequence-Initiating Actions: The Case of Explicit Account Solicitations. Discourse Studies, 12, 501-533. https://doi.org/10.1177/1461445610371051

Robinson, J. D. (2016). Accountability in Social Interaction. Oxford, England: Oxford University Press.

Searle, J. R., \& Vanderveken, D. (1985). Foundations of Illocutionary Logic. Cambridge: Cambridge University Press. https://doi.org/10.1007/1-4020-3167-X_5

Sidnell, J. (2010). Conversation Analysis: An Introduction. Boston, MA: Wiley-Blackwell. Van Dijk, T. A. (1977). Text and Context. London: Longman. 